\title{
FORMULA MAKANAN TRADISIONAL BUBUR KAMPIUN INSTAN
}

\section{Traditional Food Formula of Kampiun Instant Porridge}

\section{Yulia Helmi Diza}

Balai Riset dan Standardisasi Industri Padang

JI. Raya LIK No. 23 Ulu Gadut Padang 25164

Telp. (0751) 72201 Fax.(0751) 71320

*e-mail: yulia_dz@yahoo.com

\section{ABSTRAK}

Penelitian formula makanan tradisional bubur kampiun instan telah dilakukan melalui tiga tahapan. Pertama, tahap optimasi proses pembuatan bahan pengisi bubur kampiun instan, yang terdiri dari kacang hijau instan, bubur beras instan, bubur ketan hitam instan dan pisang instan. Kedua, pembuatan formula kuah bubur kampiun instan, dan ketiga, pencampuran bahan pengisi dan formula kuah menjadi bubur kampiun instan. Dari 8 (delapan) formulasi, perlakuan F7 yang menggunakan formula kuah E7 (santan powder instan : palmsuiker : gula pasir : susu adalah $1: 0,5: 0,5: 0,25)$ merupakan perlakuan yang cenderung lebih disukai oleh panelis. Dilihat dari kandungan gizi dan kalori, bubur kampiun instan mengandung lemak, protein dan karbohidrat yang baik. Kandungan lemak sebesar 5,70-8,94\%, protein sebesar 4,36-20,46\% dan karbohidrat sebesar 26,73-32,61\%. Sedangkan nilai kalori sebesar 180,27254,62 kkal. Karena itu bubur kampiun instan ini dapat dimanfaatkan sebagai salah satu alternatif untuk sarapan pagi, makanan darurat untuk daerah rawan bencana dan sebagai makanan oleh-oleh khas Sumatera Barat.

Kata kunci : formula, makanan tradisional, bubur kampiun, instan, pangan instan

\section{ABSTRACT}

The traditional food formula study of kampiun instant porridge had been carried out in three stages. Firstly, the optimization of the process to make filler of kampiun instant porridge, which consisted of instant mung beans, instant rice porridge, black glutinous rice porridge and banana instant. Secondly, preparation of sauce formula, and thirdly the mixing of fillers and formula sauce became a kampiun instant porridge. From the 8 (eight) formula, the F7 treatment that used E7 formula sauce (coconut milk powder instant: palmsuiker: sugar : milk were 1:0,5:0,5: $0,25)$ tends to be preferred by the panelists. Nutrients and calories of kampiun instant porridge had good content of fat, protein and carbohydrates. Fat content of $5.70 \%-8.94 \%$, protein content of $4.36 \%-20.46 \%$, and carbohydrate content of $26.73 \%-32.61 \%$. While the caloric value of $180.27 \mathrm{kcal}-254,62 \mathrm{kcal}$. Therefore, the kampiun instant porridge can be used as an alternative for breakfast, emergency food for disaster-prone areas and specific food souvenirs of West Sumatra.

\section{Keywords : formula, traditional food, kampiun porridge, instant, instant food}




\section{PENDAHULUAN}

Sumatera Barat terkenal kaya akan berbagai macam makanan tradisional, ada yang kering seperti keripik balado, karak kaliang, batiah, dakak-dakak dan karehkareh. Juga ada yang basah seperti serabi, serikaya, gelamai, bika dan beras rendang. Salah satu makanan tradisional yang cukup digemari adalah bubur kampiun, karena rasanya enak dan legit.

Bubur kampiun adalah campuran beberapa jenis bubur yang dicampur menjadi satu, yaitu bubur kacang hijau, bubur ketan hitam dan bubur putih. Sering juga ditambahkan dengan kolak pisang dan lopis. Selama ini bubur kampiun hanya dapat diperoleh pada waktu dan tempat tertentu saja. Biasanya penjual bubur kampiun dapat dijumpai pada pagi hari sebagai salah satu alternatif sarapan pagi, atau pada waktuwaktu khusus seperti pada saat pesta dan bulan puasa.

Ditinjau dari segi ketersediaan bahan baku utama seperti kacang hijau, beras, beras ketan hitam, dan pisang, daerah Sumatera Barat sangatlah mendukung. Sesuai data yang dikeluarkan oleh BPS Sumatera Barat tahun 2008, produksi kacang hijau di Sumatera Barat tersebar di beberapa daerah kabupaten/kota, seperti Pesisir Selatan, Pasaman, Dharmasraya dan Pasaman Barat adalah sebesar 1.434 ton dengan luas area produksi $1.227 \mathrm{Ha}$. Untuk beras, dihasilkan sebesar 1.965 .634 ton dengan luas area prouksi $421.902 \mathrm{Ha}$. Sementara untuk pisang, dihasilkan sebesar 39.131 ton.

Instan berarti langsung atau tanpa dimasak lama, dapat dimakan atau dapat diminum (Kamus besar Bahasa Indonesia, 2001). Instanisasi merupakan suatu istilah yang mencakup berbagai perlakuan, baik kimia ataupun fisika yang akan memperbaiki karakteristik hidrasi dari suatu produk pangan dalam bentuk bubuk. Menurut Hartomo dan Widiatmoko, 1993, pangan instan merupakan bahan makanan yang mengalami proses pengeringan air, sehingga mudah larut dan mudah disajikan hanya dengan menambahkan air panas atau air dingin.
Pangan instan juga didefinisikan sebagai produk pangan yang di dalam penyajiannya melibatkan pencampuran air atau susu dan dilanjutkan dengan berbagai proses pemasakan. Oleh karena itu bahan pangan dapat disebut sebagai pangan instan apabila memenuhi beberapa kriteria, yaitu : a) sifat hidrofilik, yaitu sifat mudah mengikat air, b) tidak memiliki lapisan gel yang tidak permeabel sebelum digunakan yang dapat menghambat laju pembasahan, c) rehidrasi produk tidak menghasilkan produk yang menggumpal dan mengendap (Hendy, 2007).

Penilaian terhadap mutu produk pangan memiliki dua aspek yaitu penilaian pembedaan sifat sensoris dan penilaian pemilihan sifat sensoris atau intensitas mutu secara keseluruhan. Faktor-faktor yang dapat mempengaruhi kevalidan data antara lain panel, laboratorium, penyajian sampel produk, dan hal-hal yang mempengaruhi pada saat pengukuran produk (sikap, motivasi, kesalahan-kesalahan psikologis dalam penilaian, adaptasi) (Nurmalisari, dkk, 2009).

Atas dasar pertimbangan itu maka penelitian dilakukan dengan maksud untuk mendapatkan formula yang terbaik dalam pembuatan bubur kampiun instan, yang ditandai dengan terpenuhinya kriteria sebagai pangan instan. Untuk itu maka dalam pembuatan formula bubur kampiun instan, dilakukan dalam beberapa tahap, yaitu: pertama, tahap optimasi proses pembuatan bahan pengisi bubur, yang terdiri atas kacang hijau instan, bubur beras instan, bubur ketan hitam instan dan pisang instan. Kedua, tahap pembuatan formula kuah bubur dan ketiga, pencampuran formula kuah dengan bahan pengisi bubur kampiun.

Dengan pentahapan yang demikian, diharapkan akan mendapat hasil yang maksimum, yang dengan mudah dapat digunakan oleh industri pangan, khususnya yang ada di Sumatera Barat sekaligus mampu memperluas pasar makanan tradisional karena dapat disimpan dalam waktu yang lama dan mudah dalam pendistribusiannya serta sebagai salah satu upaya dalam penganekaragaman pangan. 


\section{METODOLOGI PENELITIAN}

\section{Bahan}

Bahan yang digunakan dalam penelitian ini meliputi kacang hijau, tepung beras, beras ketan hitam, pisang kepok, palmsuiker, santan bubuk instan, gula pasir, susu bubuk instan, garam halus, daun pandan, jahe, kulit manis (cassiavera), natrium bicarbonate $\left(\mathrm{NaHCO}_{3}\right)$, natrium metabisulfit $\left(\mathrm{Na}_{2} \mathrm{~S}_{2} \mathrm{O}_{5}\right)$, bahan dan bahan kimia untuk pengujian.

\section{Alat}

Peralatan yang digunakan meliputi; panci stainlessteel, waskom, pisau stainlessteel, talenan, saringan, sendok kayu, rice cooker, kukusan, kompor, oven, sealer, plastik kemasan dan peralatan untuk pengujian.

\section{Rancangan Penelitian}

Proses pembuatan formula bubur kampiun instan ini dilakukan dalam 3 (tiga) tahapan, yaitu tahap optimasi proses pembuatan bahan pengisi bubur, tahap penyusunan formula (formulasi) kuah bubur dan tahap pencampuran bahan pengisi bubur dengan formula kuah, sehingga menjadi bubur kampiun instan.

Tahap 1. Optimasi proses pembuatan bahan pengisi bubur kampiun instan

A. Kacang hijau instan

A1. Kacang hijau yang sudah direndam dengan air dimasak dengan kompor

A2. Kacang hijau yang sudah direndam dengan air dimasak dengan rice cooker

A3. Kacang hijau langsung dimasak dengan rice cooker

A4. Kacang hijau langsung dimasak dengan kompor sampai empuk

A5. Kacang hijau yang sudah direndam dengan air, kemudian dengan larutan natrium bicarbonate $1 \%$ (soda kue), dimasak dengan kompor sampai empuk
Semua bahan yang telah mendapat perlakuan kemudian dikeringkan menggunakan oven

B. Bubur beras putih instan

B1. Beras putih yang sudah direndam dimasak jadi bubur

B2. Beras putih yang sudah berbentuk tepung dimasak jadi bubur

Semua bahan yang telah mendapat perlakuan kemudian dikeringkan menggunakan oven

C. Bubur beras ketan hitam instan

C1. Ketan hitam dikukus sampai empuk

C2. Ketan hitam direbus sampai empuk

C3. Ketan hitam langsung dimasak sampai airnya habis

C4. Ketan hitam yang sudah direndam dengan air dimasak sampai jadi bubur dan airnya habis

C5. Ketan hitam yang sudah direndam dengan air, kemudian direndam dengan larutan natrium bicarbonate $1 \%$, disangrai dan dimasak sampai menjadi bubur.

Semua bahan yang telah mendapat perlakuan kemudian dikeringkan menggunakan oven

D. Pisang instan

D1. Pisang direbus, diiris tipis, dikukus

D2. Pisang diiris tipis, direndam dengan natrium meta bisulfit $0,1 \%$, dan dikukus

D3. Pisang diiris tipis, rendam dengan natrium bicarbonat $1 \%$, dan dikukus

D4. Pisang diris tipis, direndam dengan natrium meta bisulfit $0,1 \%$, dikukus dengan larutan natrium bicarbonate $1 \%$

Semua bahan yang telah mendapat perlakuan kemudian dikeringkan menggunakan oven

Tahap 2. Formulasi kuah bubur kampiun instan (E)

Kuah bubur kampiun terdiri dari bahanbahan utama sebagai berikut:

- santan powder instan

- palmsuiker

- gula pasir

- susu bubuk instan 
Bahan-bahan tambahan sebagai pembentuk flavour:

- garam halus

- daun pandan

- kulit manis

- jahe

Formulasi dilakukan dengan variasi bahan-bahan utama yang menghasilkan 8 (delapan) macam perlakuan dengan penambahan bahan tambahan dalam jumlah yang sama. Kedelapan formulasi tersebut adalah sebagai berikut:

E1. Santan powder instan:palmsuiker (1:1)

E2. Santan powder instan:palmsuiker $(1: 1,5)$

E3. Santan powder instan:palmsuiker.gula pasir $(1: 0,5: 0,5)$

E4. Santan powder instan:palmsuiker.gula pasir $(1: 0,75: 0,75)$

E5. Santan powder instan:palmsuiker:susu $(1: 1: 0,25)$

E6. Santan powder instan:palmsuiker:susu $(1: 1,5: 0,25)$

E7. Santan powder instan:palmsuiker: gula pasir:susu (1:0,5:0,5:0,25)

E8. Santan powder instan: palmsuiker. gula pasir:susu $(1: 0,75: 0,75: 0,25)$

Tahap 3. Pencampuran bahan pengisi dengan formula kuah bubur $(F)$

Hasil yang optimal dari proses pembuatan bahan-bahan pengisi bubur kampiun instan, ditimbang dalam jumlah tertentu, selanjutnya dicampur dengan formula kuah yang telah dibuat, menghasilkan 8 (delapan) formula bubur kampiun instan, seperti pada Gambar 1.

\begin{tabular}{|c|}
$\begin{array}{c}\text { Formula bahan } \\
\text { pengisi } \\
(\text { Penelitian thp 1) }\end{array}$ \\
(Penelitian thp 1)
\end{tabular}$\rightarrow \begin{gathered}\text { Formulasi kuah } \\
\text { Instan (F) }\end{gathered}$

$\begin{array}{ccc}\text { Ax:Bx:Cx:Dx } & \text { E1 } & \text { F1 } \\ (3: 1: 3: 1) & \text { E3 } & \text { F2 } \\ & \text { E4 } & \text { F3 } \\ & \text { E5 } & \text { F5 } \\ & \text { E6 } & \text { F6 } \\ & \text { E7 } & \text { F7 } \\ & \text { E8 } & \text { F8 }\end{array}$

Gambar 1. Formulasi pembuatan bubur kampiun instan

\section{Analisis dan Pengamatan}

Analisis yang dilakukan terhadap bubur kampiun instan meliputi analisis kimia, fisika dan organoleptik.

1. Analisis kimia

a. Bahan pengisi bubur $(A, B, C, D)$ : kadar air dengan metode oven.

b. Bubur kampiun instan $(F)$ : analisa protein dengan metode Kjeldahl, karbohidrat dengan metode Luff Schoorl, lemak dengan metode weibull dan kalori.

2. Uji fisika terhadap bahan pengisi bubur $(A, B, C, D)$, meliputi waktu rehidrasi dengan metode uji seduh dan kemampuan penyerapan air dengan metode oven.

3. Uji organoleptik

Uji organoleptik yang digunakan adalah uji kesukaan yang menyangkut penilaian panelis terhadap sifat produk. Dalam uji ini panelis diminta tanggapan pribadinya tentang kesukaan dan ketidaksukaannya. Skor penilaian organoleptik adalah 1 sampai 5 yang dilakukan oleh 15 (lima belas) orang panelis. Data diuji dengan analisis non parametrik, menggunakan uji Kruskal-Wallis. Parameter organoleptik yang diamati meliputi penampakan, rasa, aroma dan tekstur.

\section{HASIL DAN PEMBAHASAN}

\section{Optimasi Proses Pembuatan Bahan Pengisi Bubur Kampiun Instan}

\section{Kacang hijau instan}

Dari lima perlakuan yang telah dilakukan pada proses optimasi pembuatan kacang hijau instan, dapat dilihat pada Gambar 2 hasil uji kadar air dan waktu rehidrasi. Ternyata perlakuan A5 memberikan hasil yang cenderung lebih baik dengan kadar air 5,45\% dan waktu rehidrasi paling cepat, yaitu 2,15 menit. Waktu rehidrasi adalah waktu penyerapan air kembali ke dalam bahan kering atau pati yang sebelumnya telah mengalami gelatinisasi (Winarno, 1997). Waktu rehidrasi ini penting, karena merupakan salah satu kriteria yang 
menentukan dalam pangan instan. Di samping itu, perlakuan A5 mempunyai kemampuan menyerap air sebesar $267,98 \%$. Hal ini disebabkan pada perlakuan A5, dilakukan proses perendaman yang bertujuan untuk meningkatkan kandungan air dalam biji kacang hijau sehingga memperpendek waktu masak biji kacang hijau menjadi bubur (Achadiyah, 2000).

Selain itu juga dilakukan perendaman dengan menggunakan natrium bicarbonate atau yang lebih dikenal dengan nama soda kue. Perendaman dengan larutan Natrium bicarbonate ini, membantu proses pengembangan pori pada biji kacang hijau yang sangat berperan dalam proses penyerapan air kembali (Anwar, 2011).

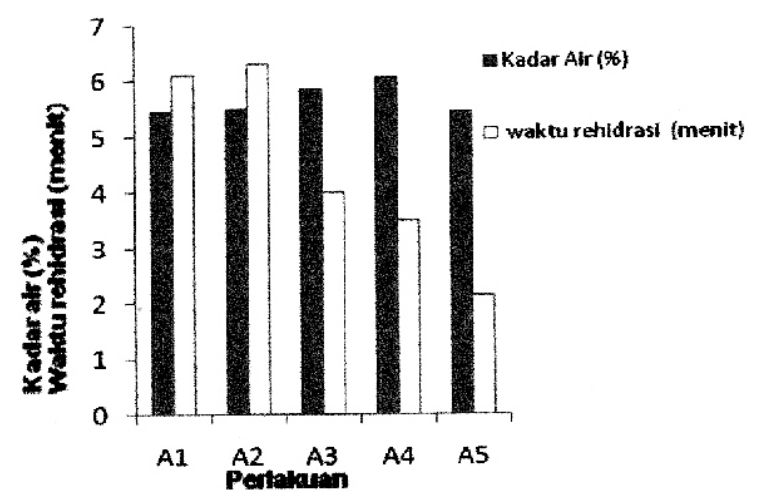

Gambar 2. Kadar air dan waktu rehidrasi kacang hijau instan dari beberapa perlakuan

\section{Bubur beras putih instan}

Pada proses optimasi pembuatan bubur beras putih instan, telah dilakukan dua perlakuan, yaitu perlakuan pertama menggunakan beras sebagai bahan baku dan perlakuan kedua menggunakan tepung beras sebagai bahan baku. Dari hasil uji kadar air dan lama waktu rehidrasi, kedua perlakuan ini memberikan hasil yang tidak jauh berbeda.

Namun demikian, perlakuan kedua (B2) memberikan hasil sedikit lebih baik dan lebih efisien karena tidak lagi melakukan proses penepungan. Dari Gambar 3 dapat dilihat bahwa perlakuan B2 memiliki kadar air $8,79 \%$ dan lama waktu rehidrasi 1,30 menit. Kadar air ini memenuhi persyaratan kadar air pangan instan seperti pada bihun instan
(SNI 01-342-1995) dan kadar air pada tepung beras (SNI 01-3549-1994). Dilihat dari waktu rehidrasi juga memenuhi persyaratan untuk pangan instan dengan waktu rehidrasi 3 sampai 5 menit.

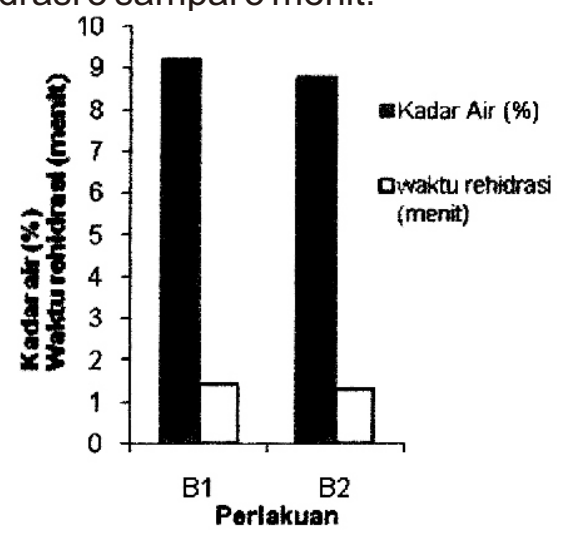

Gambar 3. Kadar air dan waktu rehidrasi
bubur beras instan dari beberapa
perlakuan

Kemampuan bubur beras putih instan dalam menyerap air kembali cukup besar, yaitu $663,99 \%$. Hal ini disebabkan karena proses gelatinisasi terjadi dengan sempurna (Winarno, 1997). Dengan demikian perlakuan kedua (B2) yang akan digunakan sebagai bahan pencampur dalam formulasi bubur kampiun instan.

\section{Bubur ketan hitam instan}

Telah dilakukan lima perlakuan dalam proses optimasi pembuatan bubur ketan hitam instan. Namua hasilnya belum begitu baik. Kesulitannya disebabkan karena beras ketan merupakan beras dengan kadar amilopektin yang sangat tinggi, nasinya sangat mengkilap, sangat pulen, dan kerapatan antar butir nasi tinggi, sehingga volume nasinya sangat kecil. Salah satu usaha untuk mengurangi sifat pulen dari amilopektin pada beras ketan hitam adalah dengan menyangrainya sebelum dimasak. Hal ini dimaksudkan untuk mengurai pati menjadi fraksi-fraksi yang lebih sederhana, seperti dekstrin yang larut dalam air.

Dari Gambar 4 dapat dilihat bahwa perlakuan C1 mempunyai waktu rehidrasi yang panjang, yaitu 15 menit. Dilihat dari persyaratan pangan instan, perlakuan yang memenuhi persyaratan pangan instan 
adalah perlakuan $\mathrm{C} 5$ dengan waktu rehidrasi 4,00 menit, kadar air 5,44\% dan kemampuan menyerap air sebesar 303,20\%. Dengan demikian perlakuan inilah yang akan digunakan sebagai bahan pencampur dalam formulasi bubur kampiun instan.

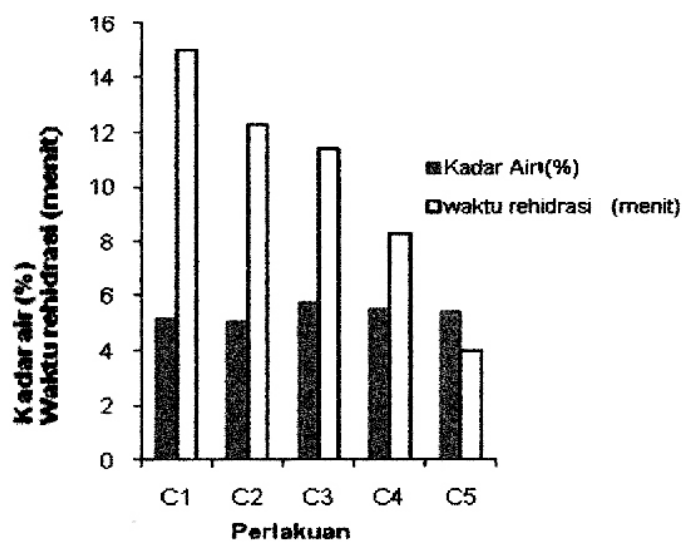

Gambar 4. Kadar air dan waktu rehidrasi bubur beras ketan hitam instan dari beberapa perlakuan

\section{Pisang instan}

Pada proses optimasi pembuatan pisang instan, telah dilakukan empat perlakuan, seperti pada Gambar 5, menggambarkan pengukuran kadar air dan waktu rehidrasi, yang menjadi persyaratan penting dalam pangan instan. Hasil pengukuran memperlihatkan bahwa perlakuan D4 memberikan hasil yang cenderung lebih baik dengan kadar air 4,63\% dan waktu rehidrasi 3 menit. Hal ini disebabkan karena pada perlakuan D4, pisang dikukus dengan menggunakan larutan natrium bikarbonat yang membantu proses pengembangan pori pada pisang.

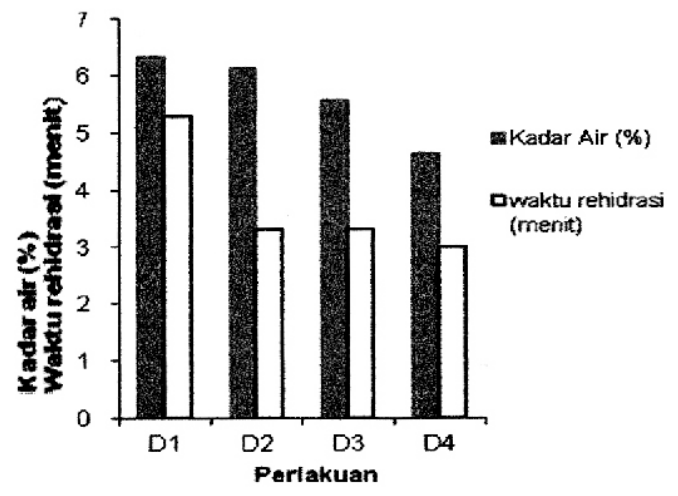

Gambar 5. Kadar air dan waktu rehidrasi pisang instan dari beberapa perlakuan
Disamping itu pada perlakuan D4, pisang instan yang diperoleh memiliki warna yang lebih cerah dari perlakuan lainnya karena pisang yang telah diiris tipis direndam terlebih dahulu di dalam larutan natrium metabisulfit. Perendaman ini bertujuan untuk mencegah terjadinya reaksi browning, karena natrium metabisulfit merupakan inhibitor yang kuat untuk mencegah terjadinya reaksi browning, baik secara enzimatis maupun non enzimatis (Istiningsih,2003).

\section{Bubur Kampiun Instan (F)}

\section{Organoleptik}

Untuk mengetahui tingkat penerimaan panelis terhadap bubur kampiun instan, dilakukan uji organoleptik. Hasil uji organoleptik, ditampilkan pada Tabel 1. Dari hasil uji organoleptik yang meliputi penampakan, rasa, aroma dan tekstur terhadap beberapa formula campuran bubur kampiun instan, rata-rata panelis memberikan nilai suka terhadap semua formulasi. Nilai tertinggi untuk penampakan diberikan oleh perlakuan $\mathrm{F} 1$, nilai tertinggi untuk rasa diberikan oleh perlakuan $\mathrm{F} 7$, nilai tertinggi untuk aroma diberikan oleh perlakuan F1 dan F7. Sedangkan nilai tertinggi untuk tekstur diberikan oleh perlakuan F1.

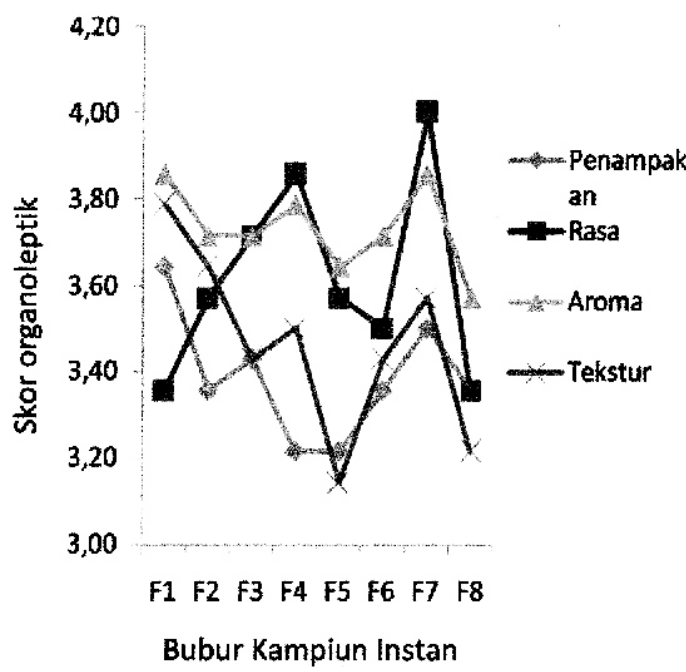

Gambar 6. Grafik rata-rata penilaian organoletikoleh panelis

Hasil analisis statistik terhadap data organoleptik bubur kampiun instan dengan 
metode Kruskal-Wallis menunjukkan bahwa perlakuan formula kuah tidak memberikan perbedaan yang nyata terhadap penampakan, rasa, aroma dan tekstur dari bubur kampiun instan. Namun dari delapan formula yang dilakukan, perlakuan $\mathrm{F} 1$ dan F7 adalah perlakuan yang cenderung lebih disukai oleh panelis.

\section{Kadar lemak}

Hasil analisa lemak pada berbagai perlakuan formula bubur kampiun instan ditampilkan pada Gambar 6 .

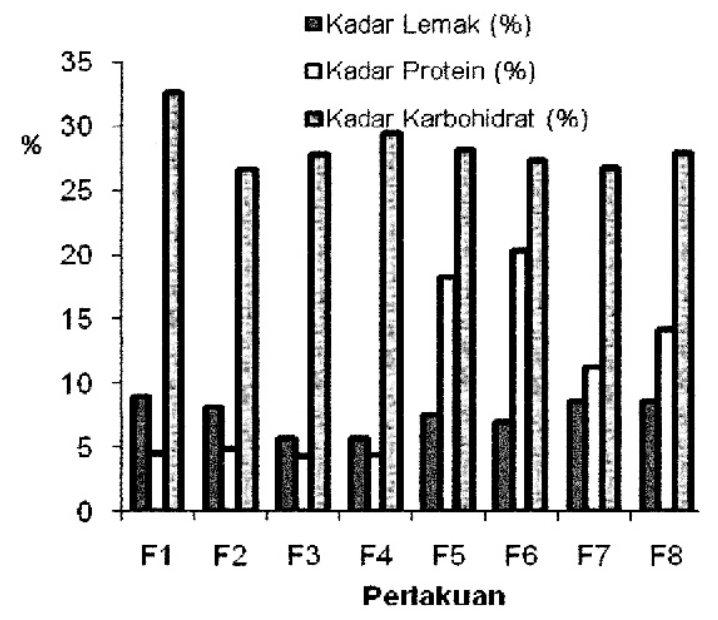

Gambar 7. Kadar lemak, protein dan karbohidrat bubur kampiun instan dari beberapa perlakuan

Dari hasil tersebut terlihat, bahwa kandungan lemak berkisar dari 5,70\% (perlakuan F4) sampai dengan 8,94\% (perlakuan F1). Kandungan lemak yang cukup tinggi ini berasal dari bahan-bahan pencampur dalam bubur kampiun instan, yaitu kacang hijau, beras ketan hitam, beras putih dan pisang yang termasuk kedalam jenis lemak nabati.

Lemak nabati mengandung asamasam lemak esensial seperti asam linoleat, linolenat dan arakidonat yang termasuk asam-asam lemak tak jenuh yang dapat mencegah penyempitan pembuluh darah akibat penumpukan kolesterol (Winarno, 1997). Kandungan lemak juga berasal dari bahan pencampur kuah, yaitu santan powderdan susu.

\section{Kadar protein}

Hasil analisis protein pada berbagai perlakuan formulasi bubur kampiun instan ditampilkan pada Gambar 6. Dari Gambar dapat dilihat bahwa kandungan protein paling rendah adalah pada perlakuan F3 yaitu sebesar $4,36 \%$ dan tertinggi pada perlakuan F6 yaitu sebesar $20,46 \%$. Dari hasil tersebut terlihat adanya perbedaan kandungan protein yang cukup tinggi antara perlakuan $F 1, F 2, F 3$ dan $F 4$ dengan perlakuan F5, F6, F7 dan F8. Perbedaan ini disebabkan karena perbedaan komponen penyusun formula kuah, dimana pada perlakuan F5, F6, F7 dan F8 formula kuahnya dicampur dengan susu. Hal ini menyebabkan kandungan protein pada perlakuan tersebut lebih tinggi dari perlakuan lainnya.

Sumber protein lainnya adalah biji kacang hijau, dan dalam jumlah kecil dari pisang, beras putih dan beras ketan hitam. Berdasarkan jumlahnya, protein merupakan penyusun utama kedua setelah karbohidrat pada kacang hijau yang mengandung banyak asam amino esensial dengan nilai daya cerna yang baik yaitu sebesar $76,54 \%$ sampai $77,34 \%$ dan meningkat menjadi 81 $\%$ melalui proses perendaman, perkecambahan dan pengolahan (Afrian, 2002), sehingga merupakan salah satu sumber protein yang sangat baik.

\section{Kadar karbohidrat}

Hasil analisa karbohidrat tidak memperlihatkan perbedaan yang mencolok dari setiap perlakuan. Dari Gambar 6 dapat dilihat kandungan karbohidrat berkisar dari $26,73 \%$ (perlakuan F2) sampai dengan $32,61 \%$ (perlakuan F1). Hal ini disebabkan bahan pencampur bubur kampiun instan (kacang, hijau, bubur ketan hitam, bubur beras putih dan pisang instan) untuk setiap perlakuan diberikan dengan jumlah perbandingan yang sama.

\section{Nilai kalori}

Angka kecukupan gizi rata-rata yang dianjurkan per orang per hari terhadap kebutuhan kalori dibedakan berdasarkan berat badan, tinggi badan, golongan umur dan jenis kelamin. Rata-rata kebutuhan 
kalori untuk pria dewasa adalah 2800 $\mathrm{kkal} / \mathrm{hari}$, untuk wanita dewasa 2200 $\mathrm{kkal} /$ hari dan untuk anak-anak $1900 \mathrm{kkal} / \mathrm{hari}$ (Widya Karya Nasional Pangan dan Gizi, 1993).

Hasil analisis terhadap beberapa perlakuan bubur kampiun instan, nilai kalori yang terbesar diberikan oleh perlakuan F6 yaitu 254,62 kkal, dan yang terendah diberikan oleh perlakuan F3 yaitu 180,27 kkal (Gambar 7).

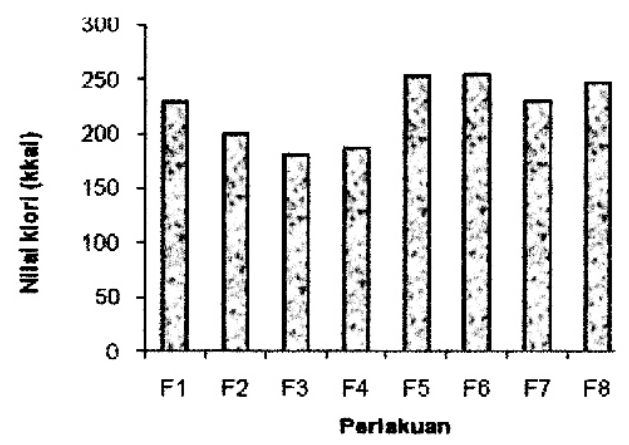

Gambar 8. Nilai kalori bubur kampiun instan dari beberapa perlakuan

Bubur kampiun instan ini dapat digunakan sebagai makanan untuk sarapan karena kandungan gizinya yang baik. Untuk memenuhi kebutuhan kalori sebagai sarapan pagi, disarankan untuk menambah porsi bubur kampiun instan dalam penyajiannya.

\section{KESIMPULAN}

Dari proses optimasi diperoleh perlakuan yang paling optimal dari bahan-bahan penyusun bubur kampiun instan, yaitu: untuk kacang hijau instan adalah perlakuan A5 (kacang hijau direndam dengan air, dilanjutkan dengan larutan natrium bikarbonate $1 \%$, dimasak dengan kompor sampai empuk). Untuk bubur putih instan adalah perlakuan B2 (beras putih yang sudah berbentuk tepung dimasak jadi bubur), untuk bubur ketan hitam instan adalah perlakuan C5 (ketan hitam yang sudah direndam dengan air, kemudian direndam dengan larutan natrium bicarbonate $1 \%$, disangrai dan dimasak sampai menjadi bubur), dan untuk pisang instan adalah perlakuan D4 (pisang diris tipis, direndam dengan Na-meta bisulfit
$0,1 \%$, dikukus dengan larutan natrium bicarbonate $1 \%$ ). Hasil uji organoleptik memperlihatkan bahwa rata-rata panelis memberikan nilai suka terhadap semua formulasi bubur kampiun instan. Tetapi dari 8 (delapan) formulasi, perlakuan F7 yang menggunakan formulasi kuah E7 (santan powder instan:palmsuiker:gula pasir:susu= 1:0,5:0,5:0,25) merupakan perlakuan yang cenderung lebih disukai oleh panelis. Dilihat dari kandungan gizi dan kalori, bubur kampiun instan mengandung lemak, protein dan karbohidrat yang baik. Kandungan lemak sebesar $5,70 \%-8,94 \%$, protein sebesar 4,36\%-20,46\% dan karbohidrat sebesar $26,73 \%-32,61 \%$. Sedangkan nilai kalori sebesar 180,27 kkal-254,62\%. Karena itu bubur kampiun instan ini dapat dimanfaatkan sebagai salah satu alternatif untuk sarapan pagi, makanan darurat untuk daerah rawan bencana dan sebagai makanan oleh-oleh khas Sumatera Barat.

\section{SARAN}

Bubur kampiun instan yang dihasilkan masih memiliki beberapa kelemahan, yaitu proses pengeringan dan pengemasan yang belum baik. Oleh karena itu perlu dilakukan penelitian lebih lanjut untuk memperbaiki proses pengeringan dan menentukan jenis kemasan yang baik sehingga bubur kampiun instan layak untuk dijual.

\section{DAFTAR PUSTAKA}

Achadiyah, S., dan Atriyanti. 2000. Lama Perendaman dan Suhu Pengukusan, Pengaruhnya Terhadap Tepung Kacang Hijau Instan Yang Dihasilkan. Buletin IImiah Instiper, 7(2):32-41

Afrian, R.N. 2002. Mempelajari Sifat Kimia, Mutu Gizi, Sifat Fisik dan Organoleptik Bubur Kacang Hijau Instan. Skripsi, Fakultas Pertanian Bogor: Institut Pertanian Bogor.

Anwar, F. 2011. Beras Singkong Semi Instan. http://kebun-singkong. blogspot.com/ 2011/05/membuat-beras-singkong/ html, diakses 17 Juni 2011. 
Badan Pusat Statistik Sumatera Barat. 2005. Luas Panen, Produksi dan Produktivitas Padi/Palawija Sumatera Barat. Padang: BPS

Dewan Standardisasi Nasional. 1995. Bihun Instan. Standar Nasional Indonesia 01 342 - 1995. Jakarta. DSN

Dewan Standardisasi Nasional. 1994. Tepung Beras. Standar Nasional Indonesia 01-3549-1994. Jakarta. DSN.

Hartomo, A.J., dan M.C. Widiatmoko. 1993. Emulsi dan Pangan Instan Ber - lesitin. Yogyakarta. Andi Offset.

Hendy, 2007. Formulasi Bubur Instan Berbasis Singkong (Manihot esculenta Crantz) sebagai Pangan Pokok Alternatif. Tesis, Fakultas Teknologi Pertanian. Bogor: Institut Pertanian Bogor.
Istiningsih, N. 2003. Pengaruh Arah Irisan Dan Konsentrasi Larutan Natium Metabisulfit $\left(\mathrm{Na}_{2} \mathrm{~S}_{2} \mathrm{O}_{5}\right)$ Terhadap Mutu Keripik Kentang (Solanum tuberosum L). (http:// student-research.umm. ac.id/index. php/dept_of_agribisnis /article/view/3160, Diakses 17 Juni 2011.

Kamus Besar Bahasa Indonesia. 2001. Tim Penyusun Kamus Pusat Bahasa. Balai Pustaka. Jakarta.

Nurmalitasari, D. 2009. Faktor-Faktor yang Mempengaruhi Pengukuran Sensoris. Faperta. Universitas Jenderal Soedirman.

Widya Karya Nasional Pangan dan Gizi V. 1993. Daftar Angka Kecukupan Gizi Yang Dianjurkan (per orang per hari). Jakarta

Winarno, F.G. 1997. Kimia Pangan dan Gizi. Jakarta: PT.Gramedia. 
